\title{
Intersexual Differences in Executive Functions in Adolescents
}

\author{
Viktor Gatial, Andrea Juhásová \\ Constantine The Philosopher University in Nitra, Tr. A. Hlinku 1, 949 74, Nitra, Slovak Republic
}

\begin{abstract}
The authors of this study pay attention to several aspects of executive functions (such as the biological and social determinations, their types and disorders) and they implement research with the goal of finding out whether, in the adolescent developmental stage, the scale of executive functions exhibits significant differences when differentiated by gender.
\end{abstract}

Keywords - adolescence, puberty, executive functions, intersexual differences.

\section{Introduction}

The puberty and adolescence developmental stages are two of the most important ones from the viewpoint of the individual's future ability to adapt. For the adolescents to reach the next developmental stages with an appropriate ability to adapt in a social environment, they have to fulfill several developmental tasks, which according to Erikson [1] leads to the creation of a personal identity, in the best case, in a positive direction (i.e. in accordance with the requirements of the society where the young individual lives). The identity of an adolescent is saturated by self-knowledge in several basic areas (sexual, cognitive, social, emotional, professional) and is achievable only through sufficient completion of the abovementioned developmental tasks. This, however, is influenced by many factors, external and internal.

DOI: 10.18421/SAR31-05

https://doi.org/10.18421/SAR31-05

Corresponding author: Viktor Gatial, Constantine The Philosopher University in Nitra, Tr. A. Hlinku 1, 949 74, Nitra, Slovak Republic.

Email: vgatial@ukf.sk

Received: 12 February 2020.

Revised: 06 March 2020.

Accepted: 14 March 2020.

Published: 30 March 2020.

(cc)BY-NC-ND (C) 2020 Viktor Gatial \& Andrea Juhásová; published by UIKTEN. This work is licensed under the Creative Commons Attribution-NonCommercial-NoDerivs 3.0 License.

The article is published with Open Access at www.sarjournal.com
One of the important internal factors in the direction of achieving a personal identity are the individual's executive functions, which several authors, e.g. Kulišt'ák [2], Koukolík [3], Carter [4], think to have an important influence on the individual's showing of normal or risk behavior in adolescence.

Executive functions have a regulative and adaptive role in the human life. From an early age, the individual learns appropriate ways to adapt, in a family setting as well as institutional environment, spontaneously and purposefully. Adolescence is, from this point of view, one of the most important developmental stages. Executive functions start developing very early in an individual's life. The ability of children to direct their attention to different objects and follow an adult's gaze develops around the first year of age. The ability to focus their attention develops rapidly in the second and third year. At the start of adolescence, therefore, the executive functions should exhibit an appropriate stage of development, given this stage is filled with difficult qualitative and quantitative developmental changes (physical, motoric, cognitive, social, emotional, moral). If the material bases of the individual's executive functions are right, their resulting levels, thus one of the steps toward an appropriate identity and adaptation, will then likely only depend on the appropriate quality and quantity of stimuli present in their social environment. The question of interest in our research was whether, then, it would be desirable to differentiate the stimuli within the social environment with regard to the adolescent's gender, and therefore fulfill their biological limit in the transcourse of their development to the best result.

\section{Chosen Attributes to Executive Functions}

The adjective "executive" is a linguistic designation of traits signifying directive, controlling, dominant, performing. In a psychological context, executive functions are most frequently designated as the directive system, assigning priority to some processes while suppressing others' activity. They are mental functions, directing cognitive functions, conditioning the processing of stimuli and 
distributing resources for their processing and utilization. They manifest in processes of inhibition, attention-checking, work memory, self-regulation and planning [5].

Some authors, for example Parkin [6], state that executive functions are nothing but a neuropsychological construct and there is no evidence of the localization of a central executive system, and therefore no area in the brain showing any connection to executive functions. Several authors, however, prove the existence of executive functions and connect them with the frontal lobe of the brain, analogically pointing to their purpose - to ensure a perfect coordination of all of the systems in the brain. The problem, however, rests in some unresolved relationships among theoretical constructs, among which is present the term "executive functions" itself. When considering the topic of executive functions, we therefore encounter a problem not only in defining the term, but also in the questions pointing to the (non-)existence of what it designates [2].

The first evidence of executive functions was recorded in the field of neuropsychology. Patients with brain damage were observed (as a result of car accidents, injuries, strokes and so on), recording mainly the level of cognitive processes and changes in them. Even as patients exhibited suitable levels of individual cognitive processes, there were changes observed such as the inability to exercise self-control, problems with executing actions, inability to plan and decide, stereotypical and impulsive reactions to diverse stimuli and situations [7].

Modern research shows that the prefrontal cortex is most likely responsible for the special and new actions in the organism, and is also called the executive of the brain or the creativity organ. It directs the cortex and therefore the basic forms of mental action. It's superior to all other structures of the brain [2]. Damage to both sides of the prefrontal cortex can cause disorders in emotional expression, and leads to inappropriate social behavior: Selfcontrol, long-term planning, abstract thinking, judgement, problem-solving, active adaptability, sense of humor, empathy and conscience are processes, states and properties that one can lose through damage to the prefrontal cortex of the brain [8].

Koukolík [3] considers the mitigation of undesirable or counterproductive behavior a key function of the prefrontal cortex. He states that the prefrontal cortex has a so-called associative function of the frontal lobe of the brain, and in human phylogenesis, as opposed to, for example primates, it achieved maximum development (it constitutes up to a third of the neocortex). It achieves full maturity toward the end of adolescence, which matches the cognitive, moral and emotional development.

Executive functions can, therefore, be understood as the range of abilities required for purposeful, goaldriven action, socially acceptable behavior and independent direction and action [9], or as the "superior executive organ" - a cohort of processes which ensure and regulate self-control, thanks to the correct regulation of cognitive functions and behavior [10]. Executive functions are defined as a multioperational system ensuring the complicated interaction of the neurological and psychological levels by Slavkovská [7]. Executive functions represent the ability to block inaproppriate reactions, resist distraction and interference, maintain behavior over time, utilize several sources of information at the same time, understand the underpinnings of complex situations, plan and execute actions in a complex manner and enable the development of new approaches to actions that were not commonly executed before [11], [12]. The term "executive functions" is mainly the domain of experts in the area of neuropsychology. The term is often connected to diverse mental disorders, such as activity and attention disorders [13].

Acccording to several authors, it is possible to determine the functional specification of the individual parts of the executive system [14] states that certain executive functions enable one to solve a certain type of problem, requiring logical thinking and abstract imagination, while others are aimed at coping with affect and the regulation of emotions and motivation. He then determines the following executive functions: Imagination or representation of the problem, planning of the solution to a problem, realisation of the plan, judgement or evaluation of the solution. Kovalč́́ková [5] considers selective attention, inhibition, work memory, planning and cognitive flexibility to be the main components of executive functioning. Guare, Dowson and Guare [15] identified eleven specific executive functions: response inhibition, work memory, emotional control, flexibility, attention concentration, work initiation, priority determination, organization, time management, goal-oriented endurance, metacognition. The authors created the Executive Skills Questionnaire based on this, which was used in our research. Miyake et al. [16] identified three kinds of executive functions: 1 . Updating - the ability to adjust work memory to effectively make use of its capacity - material made irrelevant for the current goals is removed from memory, making space for more, 2. Connection, a given task can only seldom be completed without paying attention to other tasks or redirecting to a different task, and 3. Inhibition, many times our behavior is automatic and based on having learned how to react to certain stimuli, while it is desirable for us to block strong, undesirable reactions. 
According to Preiss [17], executive functions, as long as they are not damaged, enable one to act independently, purposefully and productively. Damage to these shows adversely on an individual's behavior. According to the author, executive functions consist of four elements: will, planning, purposeful action and successful execution.

Koukolík [3] defines executive functions as directive functions, a group of cognitive functions containing the ability to create and execute plans, create analogies, respect the rules of social behavior, solve problems, adapt to new (unexpected) changes in the environment, multitask, order events correctly in space and time, store, process and use information from work memory.

In adolescence, a disturbance in executive functions can have a marking influence on academic, social and personal performance of an individual, and therefore, on their subsequent life. We can address this as the so-called dysexecutive syndrome, the general symptoms of which can be described as follows: motoric disorders ( central paresis, involuntarily averting gaze to the side, walking disruption), speech disorders (aphasia, fluidity disorders and mutism), changes in emotion and affectivity (emotional flatness, disorders of emotional control, emotional instability), personality disorders (socially unacceptable behavior, hypersexuality, loss of boundaries), apathy (disinterest in surroundings, cognitive reduction and disorders (mental rigidity, slowed thinking, confabulations) mood disorders (euphoria, increased excitability, explosions of anger), attention disorders (sensory inattention) memory disorders (forgetfulness, work memory disruption), perseverations and stereotypes in answers, echolalia and echopraxia, problems with temporal organization of actions, planning, inability to solve problems, disorganisation in actions. In dysexecutive syndrome, problems with social behavior and emotional control of the individual emerge [18]. Mental disorders such as ADHD (attention disorder caused by inappropriate activity levels) and OCD (obsessive-compulsive disorder) significantly influencing an individual's life in the developmental stage of adolescence, are connected to excessive activity on the orbitofrontal cortex [19].

Like their cognitive counterpart, executive functions also need continuous positive support from early ages in children. Until about three years old, this happens more or less extensively, depending on the biological and social conditions of the child, later - in the framework of institutionalized education conditions should be deliberately arranged to support appropriate development of executive functions. The problem, however, remains that until now, there has not been a mental function spectrum participating in the ability to learn identified on a sufficient scale. Most probably, this ability is conditioned on an interaction of several simpler mental functions, influencing the actions of other functions. If we, then, wish to develop appropriate didactic applications or interventional or developmental programs, we need to first recognize the individual components of this ability [5].

\section{Population and Sample}

Our population was made up of the pupils of the 5th through the 9th grade of primary school in the Slovak educational system, consisting of 9 grades in total. The total $\mathrm{N}$ of the population was 203172 . The sample is unsorted, i.e. children with special educational needs or individual study plans were not excluded. It was made up of 1011 adolescents with an average age of 12,75 years old (standard error of $1,483)$. The male to female ratio was $470: 500$ with 41 not stating their gender. The research was executed in all of the administrative regions of the Slovak Republic. The data was collected personally, in individual classes. The sample can be denominated stratified. There are schools from all of the administrative regions of the Slovak Republic present, from larger and smaller towns and cities, as eight schools participated in the research, one per region. Pen-and-paper questionnaires were used as the instrument. To minimize disruptions in class, the data collection was executed on a previously agreed schedule consulted with the school's administration, always during one lesson period. The pupils filling out the questionnaires were being instructed by qualified personnel throughout the process. In the interest of data protection, the survey was anonymous. The pupils whose parent or guardian expressed their disagreement with the child's participation in the research in writing, did not participate.

\section{Research Methods}

The research was executed via questionnaire. The participants filled out the Executive Skills Questionnaire, a method developed in 2010 by Dawson and Guare [15].

It consists of 33 elements the participants are to judge according to a 7-point scale, where 1 means completely disagree, 2 disagree, 3 disagree more than agree, 4 don't know, 5 agree more than disagree, 6 agree, 7 completely agree.

The questionnaire consists of 10 sub-scales:

Answer inhibition: elements express tendency to immediate action. Example: I speak faster than I think

Working Memory: elements express a tendency to ineffective use of short-term memory. Example: I forget to take note of my homework.

Emotional control: express frustration with school environment. Example: I get angry if tasks are too difficult or take too long to finish. 
Flexibility: elements express a lower ability to apply knowledge and adapt it to new situations. Example: I get angry at having to change my plans.

Sustained attention: elements express attention concentration problems. Example: It takes me a long time to finish tasks.

Task initiation: elements express problems with postponing pleasurable activities in favor of school duties. Example: I put tasks off until the last minute.

Priority determination: elements express problems with determining importance of school tasks. Example: I feel long-lasting tasks burden me.

Organization: elements express problems with ordering of personal space and duties. Example: My desk is messy.

Time management: elements express problems with temporal organization. Example: I often don't finish my homework and attempt to finish it in school, before the lesson starts.

Goal-directed persistence: elements express problems with understanding and defining goals. Example: I don't understand the point of good grades as a means of achieving long-term goals.

Metacognition: elements express evaluation of own processes as ineffective. Example: I don't check my work for errors, even with a high risk of having committed some.

All the elements are inversely formulated, i.e. describe the opposite phenomenon relating to the subscale name.

The point range in subscales is 1 to 21 points. The overall score is on a scale from 33 to 121 points.

The statistical analysis of the data was carried out using IBM SPSS 20 (Statistical Package for the Social Sciences) and STATA 13. For the description of the data, descriptive statistics were used (count, mean, standard error, SEM)

The normality of the data distribution was determined through the Kolmogorov-Smirnoff normality test. To determine the causal influence of gender on executive functions, a GLM (General Linear Model, Multivariate) was used. Before the analysis was applied, the equality of deviations was determined (Levene's test on all variables $\mathrm{p}<0.05$ ) and covariance matrix equality (Box's test,p>0,001).

The difference-in-means comparison in executive function levels between genders was tested via a Student-t test for independent choices.

\section{Results and Conclusion}

In total, we recorded no difference in executive functions in adolescents as measured by gender.

$$
(\mathrm{t}=-0,29 ; \mathrm{p}=0,772) \text { (see Table 1.). }
$$

In some subscales, executive function levels in boys and girls in the sample do differ, specifically in the emotional control $(\mathrm{t}=-3,092 ; \mathrm{p}=0,002)$ and attention concentration $(\mathrm{t}=-2,614 ; \mathrm{p}=0,009)$ subscales, in both cases in the favor of boys (see Table 1. and Graph 1.).

Even though many instances of intergender difference research in levels of executive functions have low significative value due to the small sample and bio-psycho-social influences, from metanalysis and large-n studies it can be derived that men exhibit a selective dysfunction in the form of impulsivity in executive tasks as compared to women. These findings are, however, flawed by the error of expectation and false positives. These selective executive deficits can, therefore, be a foundation for the higher levels of criminality, violence and substance abuse initiation in male individuals [20].

Differing from our results, some studies, then, present the existence of differences between genders in the maturing of the nervous system, its structure, anatomical and functional connectivity and activity, which could, in the upbringing and education of adolescents, call for different approaches according to gender, to increase efficiency.

The Slovak study on executive function levels and academic procrastination in students of universities showed that almost half $(46,5 \%)$ of the students procrastinate. These individuals also exhibit worse results in their studies. Intergender differences in procrastination were not significant. There was, however, a significantly higher level of executive functions in non-procrastinating students and a higher level of inhibition and self-monitoring in female students over males [21].

Graph 1. Individual executive function scale (subscales) with regard to gender

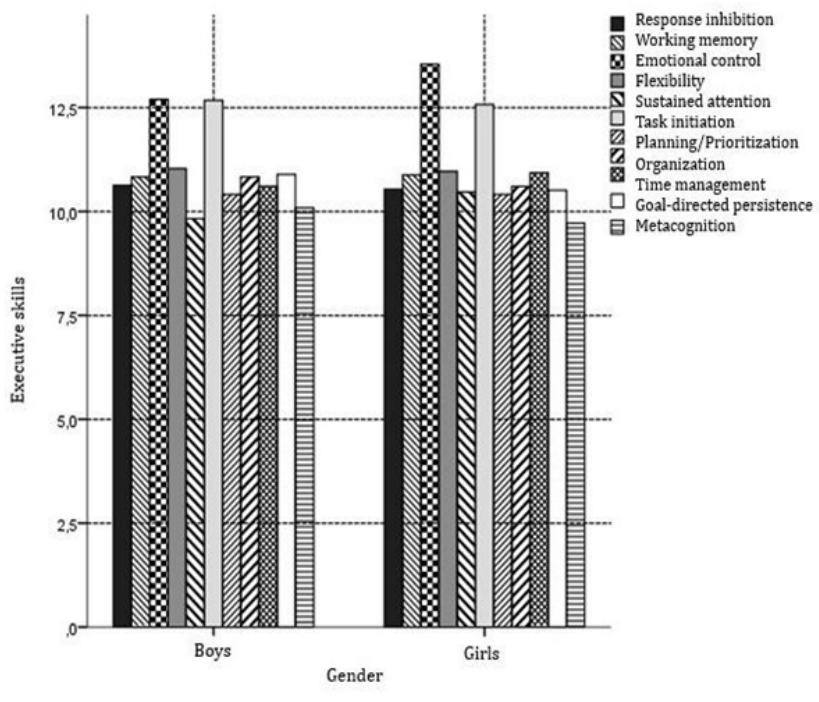


Table 1. Inter-gender comparison in levels of (individual)executive functions in adolescents (descriptive statistic also published in Čerě̌nik [22])

\begin{tabular}{|c|c|c|c|c|c|c|c|}
\hline Executive skill & Gender & $\mathrm{N}$ & $\mathrm{M}$ & SD & SEM & $\mathrm{t}$ & $\mathrm{p}$ \\
\hline \multirow{2}{*}{ Response inhibition } & $\hat{0}$ & 421 & 10,580 & 3,817 & 0,186 & \multirow{2}{*}{0,053} & \multirow{2}{*}{0,958} \\
\hline & q & 470 & 10,566 & 3,847 & 0,177 & & \\
\hline \multirow{2}{*}{ Working memory } & $\widehat{0}$ & 434 & 10,608 & 4,159 & 0,200 & \multirow{2}{*}{$-0,919$} & \multirow{2}{*}{0,359} \\
\hline & q & 475 & 10,861 & 4,129 & 0,189 & & \\
\hline \multirow{2}{*}{ Emotional control } & 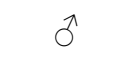 & 427 & 12,569 & 3,958 & 0,192 & \multirow{2}{*}{$-3,092$} & \multirow{2}{*}{0,002} \\
\hline & q & 474 & 13,403 & 4,116 & 0,189 & & \\
\hline \multirow{2}{*}{ Flexibility } & $\widehat{0}$ & 418 & 10,919 & 3,871 & 0,189 & \multirow{2}{*}{0,377} & \multirow{2}{*}{0,707} \\
\hline & q & 472 & 10,822 & 3,776 & 0,174 & & \\
\hline \multirow{2}{*}{ Sustained attention } & 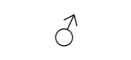 & 420 & 9,760 & 4,220 & 0,206 & \multirow{2}{*}{$-2,614$} & \multirow{2}{*}{0,009} \\
\hline & q & 474 & 10,525 & 4,501 & 0,207 & & \\
\hline \multirow{2}{*}{ Task initiation } & $\hat{0}$ & 420 & 12,426 & 4,564 & 0,223 & \multirow{2}{*}{$-0,224$} & \multirow{2}{*}{0,822} \\
\hline & q & 472 & 12,496 & 4,670 & 0,215 & & \\
\hline \multirow{2}{*}{ Planning/Prioritization } & $\widehat{\sigma}$ & 404 & 10,317 & 4,147 & 0,206 & \multirow{2}{*}{$-0,158$} & \multirow{2}{*}{0,875} \\
\hline & q & 457 & 10,361 & 4,056 & 0,190 & & \\
\hline \multirow{2}{*}{ Organization } & $\widehat{0}$ & 403 & 10,878 & 4,883 & 0,243 & \multirow{2}{*}{1,231} & \multirow{2}{*}{0,219} \\
\hline & q & 457 & 10,473 & 4,773 & 0,223 & & \\
\hline \multirow{2}{*}{ Time management } & $\widehat{0}$ & 403 & 10,568 & 3,917 & 0,195 & \multirow{2}{*}{$-1,486$} & \multirow{2}{*}{0,138} \\
\hline & $q$ & 459 & 10,974 & 4,070 & 0,190 & & \\
\hline \multirow{2}{*}{ Goal-directed persistence } & $\hat{0}$ & 405 & 10,867 & 3,575 & 0,178 & \multirow{2}{*}{1,621} & \multirow{2}{*}{0,105} \\
\hline & $q$ & 454 & 10,480 & 3,410 & 0,160 & & \\
\hline \multirow{2}{*}{ Metacognition } & $\widehat{0}$ & 403 & 10,074 & 4,061 & 0,202 & \multirow{3}{*}{1,488} & \multirow{3}{*}{0,137} \\
\hline & q & 454 & 9,665 & 3,979 & 0,187 & & \\
\hline & $\hat{0}$ & 371 & 120,499 & 30,199 & 1,568 & & \\
\hline Executive skills & $q$ & 418 & 121,136 & 31,461 & 1,539 & $-0,290$ & 0,772 \\
\hline
\end{tabular}

Legend: $\bar{O}$ - boys, $q$ - girls, $N$ - count, $M$ - arithmetic average, SEM - standard error of the mean, SD - standard deviation, $t$ - test statistic (Student's T test), $p$ - significance levels

\section{Acknowledgements}

This work was supported by the Slovak Research and Development Agency under the Contract No. APVV-150368 .

\section{References}

[1]. Erikson, E. H., \& Erikson, J. M. (1999). Životní cyklus rozšǐrený a dokončený: doplněné vydání o devátém stupni vývoje od Joan M. Eriksonové. Lidové noviny.

[2]. Kulišták, P. (2003). Neuropsychologie. Praha: Portál. 336 s., ISBN 80-7178-554-7.

[3]. Koukolík, F. (2012). Lidský mozek: Funkční systémy. Norma a poruchy. Praha: Galén.

[4]. Carter, R. et al. (2010). Mozog. Ilustrovaný sprievodca štruktúrou, funkciami a poruchami. Bratislava: Ikar.
[5]. Kovalčíková, I. (2016). Diagnostika a stimulácia kognitívnych a exekutívnych funkcii žiaka v mladšom školskom veku. Prešov: Vydavatel'stvo Prešovskej univerzity, ISBN 978-80-555-1719-3.

[6]. Parkin, A. J. (2004). Normal age-related memory loss and its relation to frontal lobe dysfunction. In Methodology of frontal and executive function (pp. 179-192). Routledge.

[7]. Slavkovská, M. (2014). Exekutívne funkcie - iný spôsob pohl'adu na naše deti. Rodina a škola. 2014, roč. 62 , č. 3 , s. $18-19$.

[8]. Damasio, R. A. (2000). Descartesův omyl. Praha: Mladá fronta.

[9]. Lyon, G. R. (1994). Frames of Reference for the Assessment of Learning Disabilities: New Views on Measurement Issues. Paul H. Brookes Publishing Co., PO Box 10624, Baltimore, MD 21285-0624.

[10]. Brown, T. E. (2006). Executive functions and attention deficit hyperactivity disorder: Implications of two conflicting views. International Journal of Disability, Development and Education, 53(1), 35-46. 
[11]. Denckla, M. B. (1996). A Theory and Model of Executive Function: A Neuropsychological Perspective. In Lyon, G. R., Krasnegor, N. A. (eds.). Attention, Memory, and Executive Function. Baltimore: Brookes, 1996.

[12]. Mahone, E. M., Cirino, P. T., Cutting, L. E., Cerrone, P. M., Hagelthorn, K. M., Hiemenz, J. R., ... \& Denckla, M. B. (2002). Validity of the behavior rating inventory of executive function in children with ADHD and/or Tourette syndrome. Archives of Clinical Neuropsychology, 17(7), 643-662.

[13]. Schöffelová, M. et al. (2012). Diagnostika exekutívnych funkcií orientačným testom dynamickej praxie. Psychológia a patopsychológia dietata, 46(1), 33-45.

[14]. Hetherington, R. (2005). What is executive function. About kids health. Retrieved from: www.aboutkidshealth.ca/ofhc/news/SREF/4144.asp [accessed: 07 September 2019].

[15]. Guare, R., Dawson, P., \& Guare, C. (2012). Smart But Scattered Teens: The" executive Skills" Program for Helping Teens Reach Their Potential. Guilford Press.

[16]. Miyake, A., Friedman, N. P., Emerson, M. J., Witzki, A. H., Howerter, A., \& Wager, T. D. (2000). The unity and diversity of executive functions and their contributions to complex "frontal lobe" tasks: A latent variable analysis. Cognitive psychology, 41(1), 49-100.
[17]. Preiss, M. (1998). Klinická neuropsychologie. Praha: Grada Publishing.

[18]. Bell, V. (2006). The executive system and its disorders. Retrieved from: www.ldchicago/execsysdisorders.pdf [accessed: 23 October 2019].

[19]. Lyketsos, C. G., Rosenblatt, A., \& Rabins, P. (2004). Forgotten frontal lobe syndrome or "Executive Dysfunction Syndrome". Psychosomatics, 45(3), 247255.

[20]. Cornblath, E. J., Tang, E., Baum, G. L., Moore, T. M., Adebimpe, A., Roalf, D. R., ... \& Bassett, D. S. (2019). Sex differences in network controllability as a predictor of executive function in youth. NeuroImage, 188, 122-134.

[21]. Schweigerová, K., \& Slavkovská, M. (2015). Akademická prokrastinácia $\mathrm{v}$ kontexte exekutívnych funkcií. E-psychologie (E-psychology), 9(2), 26-35.

[22]. Čerešník, M. (2019). Rizikové správanie, blízke vzt'ahy a sebaregulácia dospievajúcich $\mathrm{v}$ systéme nižšieho sekundárneho vzdelávania. Nitra: Vydavatel'stvo SPU. 